\title{
Migratory cellulitis: Stenotrophomonas maltophilia infection of the skin
}

\author{
Sho Fujiwara, ${ }^{1,2}$ Yuji Gokon ${ }^{1}$
}

'Department of Surgery, Iwate Prefectural Tono Hospital, Tono, Iwate, Japan

${ }^{2}$ Department of Surgery, Iwate Prefectural Chubu Hospital, Kitakami, Iwate, Japan

\section{Correspondence to}

Dr Sho Fujiwara;

sho.fujiwara@med.tohoku.ac.jp

Accepted 25 November 2020

\section{DESCRIPTION}

An 87-year-old woman visited our hospital with an abscess in her left little finger that developed following an injury during a fall in the garden in the rain a few days ago. Physical examination revealed localised redness and swelling of the left hand (figure 1) and unremarkable findings in the left upper extremity. X-ray imaging showed no fractures. We treated the patient with incisional drainage and $1 \mathrm{~g}$ cefazolin intravenously every 8 hours for 7 days for the abscess and cellulitis in her left hand, respectively. The skin infection improved immediately (figure 2). However, 4 days after treatment initiation, the patient experienced migratory cellulitis of the left upper extremity without inflammatory signs in her left hand (figure 3). Tissue culture revealed Stenotrophomonas maltophilia. The patient was diagnosed with $S$. maltophilia infection, and her treatment was switched to a 5-day course of cotrimoxazole, following which the migratory cellulitis disappeared and the patient recovered.

S. maltophilia infection of the skin in a patient who is not immunocompromised is very rare. ${ }^{1-3} S$. maltophilia is an aerobic Gram-negative bacteria and motile by its flagella. ${ }^{4}$ It produces some extracellular

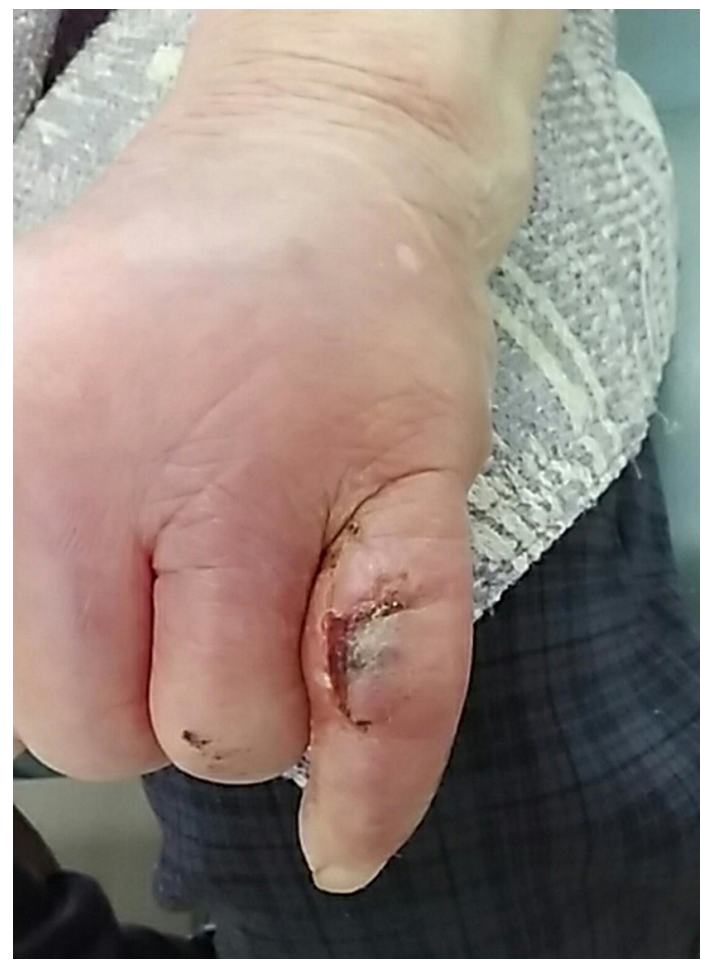

Figure 1 Localised redness and swelling of the left hand.

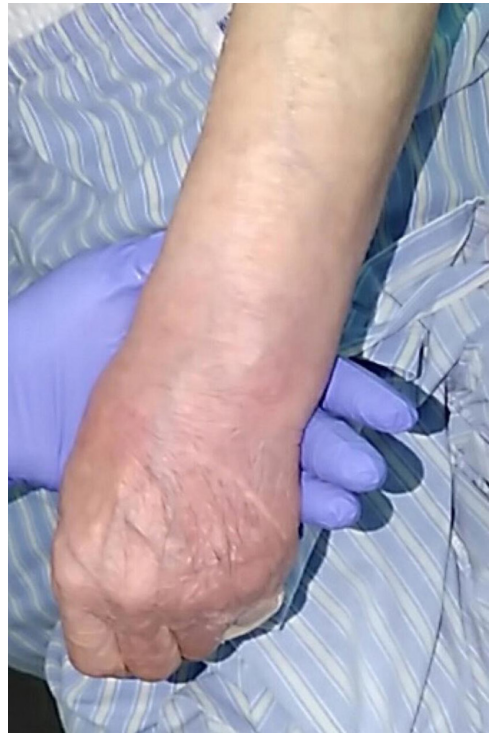

Figure 2 The skin infection improved immediately with incisional drainage and cefazolin, respectively.

enzymes: hyaluronidase, protease, elastase, lipase, DNase, RNase and fibrinolysin. ${ }^{4}$ A previous report suggested these enzymes contribute to its pathogenicity. ${ }^{5}$ These features of toxicity could cause migratory satellite cellulitis lesions. Even in a patient who is

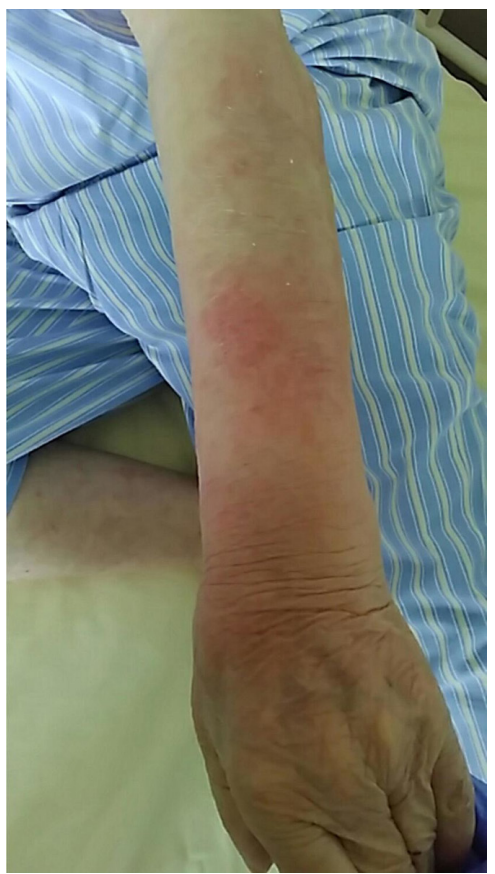

Figure 3 Migratory cellulitis of the left upper limb after treatment with cefazolin. 


\section{Learning points}

Stenotrophomonas maltophilia infection of the skin in a nonimmunocompromised patient is very rare.

- Detailed history of injury and identification of characteristic skin lesions are important in the diagnosis.

not immunocompromised and not at a high risk for skin infection, detailed history of injury and identification of characteristic skin lesions are important to accurately diagnose this infection.

Acknowledgements We would like to thank Editage (www.editage.jp) for English language editing.

Contributors SF saw the patient and wrote the manuscript. YG saw the patient and revised the manuscript.
Funding The authors have not declared a specific grant for this research from any funding agency in the public, commercial or not-for-profit sectors.

Competing interests None declared.

Patient consent for publication Next of kin consent obtained.

Provenance and peer review Not commissioned; externally peer reviewed.

\section{REFERENCES}

1 Bin Abdulhak AA, Zimmerman V, Al Beirouti BT, et al. Stenotrophomonas maltophilia infections of intact skin: a systematic review of the literature. Diagn Microbiol Infect Dis 2009:63:330-3.

2 Teo WY, Chan MY, Lam CM, et al. Skin manifestation of Stenotrophomonas maltophilia infection--a case report and review article. Ann Acad Med Singap 2006;35:897-900.

3 Batra P, Mathur P, Misra MC. Clinical characteristics and prognostic factors of patients with Stenotrophomonas maltophilia infections. J Lab Physicians 2017;9:132-5.

4 Denton M, Kerr KG. Microbiological and clinical aspects of infection associated with Stenotrophomonas maltophilia. Clin Microbiol Rev 1998;11:57-80.

5 Bottone EJ, Reitano M, Janda JM, et al. Pseudomonas maltophilia exoenzyme activity as correlate in pathogenesis of ecthyma gangrenosum. J Clin Microbiol 1986;24:995-7.

Copyright 2021 BMJ Publishing Group. All rights reserved. For permission to reuse any of this content visit

https://www.bmj.com/company/products-services/rights-and-licensing/permissions/

BMJ Case Report Fellows may re-use this article for personal use and teaching without any further permission.

Become a Fellow of BMJ Case Reports today and you can:

- Submit as many cases as you like

- Enjoy fast sympathetic peer review and rapid publication of accepted articles

- Access all the published articles

- Re-use any of the published material for personal use and teaching without further permission

\section{Customer Service}

If you have any further queries about your subscription, please contact our customer services team on +44 (0) 2071111105 or via email at support@bmj.com.

Visit casereports.bmj.com for more articles like this and to become a Fellow 